\title{
The Social Contract or Traditional Elements in the Federal Constitution of Malaysia: An Analysis of its Application
}

\section{Khadijah Muda, Nazri Muslim, Siti Nor Azhani Mohd Tohar \& Fazilah Idris}

To Link this Article: http://dx.doi.org/10.6007/IJARBSS/v11-i11/10539～DOI:10.6007/IJARBSS/v11-i11/10539

Received: 06 September 2021, Revised: 10 October 2021, Accepted: 24 October 2021

Published Online: 16 November 2021

In-Text Citation: (Muda et al., 2021)

To Cite this Article: Muda, K., Muslim, N., Tohar, S. N. A. M., \& Idris, F. (2021). The Social Contract or Traditional Elements in the Federal Constitution of Malaysia: An Analysis of its Application. International Journal of Academic Research in Business and Social Sciences, 11(11), 1001 - 1017.

\section{Copyright: (c) 2021 The Author(s)}

Published by Human Resource Management Academic Research Society (www.hrmars.com)

This article is published under the Creative Commons Attribution (CC BY 4.0) license. Anyone may reproduce, distribute, translate and create derivative works of this article (for both commercial and non-commercial purposes), subject to full attribution to the original publication and authors. The full terms of this license may be seen at: http://creativecommons.org/licences/by/4.0/legalcode

Vol. 11, No. 11, 2021, Pg. $1001-1017$

Full Terms \& Conditions of access and use can be found at http://hrmars.com/index.php/pages/detail/publication-ethics 


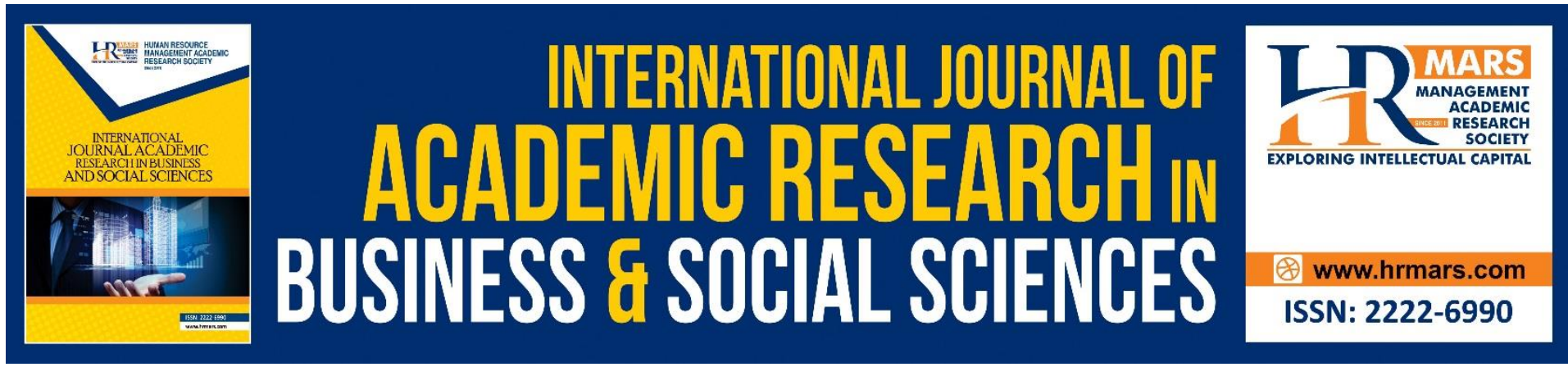

\title{
The Social Contract or Traditional Elements in the Federal Constitution of Malaysia: An Analysis of its Application
}

\author{
Khadijah Muda', Nazri Muslim², Siti Nor Azhani Mohd Tohar $^{1}$ \& \\ Fazilah Idris ${ }^{2}$ \\ ${ }^{1}$ Centre for Core Studies \& Leadership and Management Faculty, USIM, Nilai, ${ }^{2}$ School of \\ Liberal Studies (CITRA), UKM, Bangi \\ Email: khadijahmuda@usim.edu.my, azhanitohar@usim.edu.my, nazrim@ukm.edu.my
}

\begin{abstract}
Various issues on the constitution involving the traditional elements give rise to debates within the society either on social media or the electronic and print media. Traditional elements issues namely the position of Malay Rulers, the special rights of Malays, Islam and the Malay language are often debated. Through social media, various incidents for example the insultation of Sultan Muhammad V (2019) and the International Convention on the Elimination of All Forms of Racial Discrimination (ICERD) (2018) become the debate of society. This issue shows that the debate regarding the traditional elements often gains the attention of society. Traditional elements contained in the Constitution today starting from the Malacca Sultanate era. These elements are preserved according to the history of the country. all these elements need to be known and understood by the younger generation. A pilot study on the knowledge, attitude and appreciation of the traditional elements in Malaysia has been carried out. A number of two pilot studies were held involving 200 and 191 respondents through social media for example WhatsApp and Facebook. The findings from this study show that the respondents' knowledge, attitude and appreciation of the traditional elements is high. There were differences in knowledge, attitude and appreciation of the traditional elements according to ethnic. The implication of this study is that the traditional elements should be known and understood by every Malaysian to make this country in peace and harmonious.
\end{abstract}

Keywords: Social Contract, Traditional Elements, Federal Constitution, Ethnicity, Unity.

\section{Introduction}

Ever since the year 1957, Malaysia has achieved 64 years of independence. This also means that the Federal Constitution has been used for 64 years in Malaya or the country Malaysia. The Federal Constitution was printed for the very first time on 31 August 1957 and was known as the Federal Constitution of Malaya. It was then introduced as the Constitution of Malaysia on Malaysia Day, 16 September 1963 (The Commissioner of Law Revision, 2010). The Federal Constitution must be obeyed by every Malaysian citizen in order to maintain peace and harmony that exists within the multiracial society in Malaysia. The Federal Constitution is also a symbol of consensus between the three primary races in Malaya or now 
known as Malaysia, in achieving independence. Nowadays, Malaysians are seen to be unclear in regards to the consensus that was agreed upon by the races in the Federal Constitution causing today's generation to be bolder in questioning social contract issues (Awang Sariyan, 2014; Nazri Muslim et al., 2013; Siti Ajar Hj Ikhsan \& Safiah Ahmad, 2014). This study aims to analyse the traditional elements or the social contract of the Federal Constitution that has united the primary races in Peninsular Malaysia ever since the start of the Malayan Independence till today, as well as its application in the Malaysian society.

\section{Research Objectives}

Generally, this study will analyse the application of the traditional elements in the Federal Constitution in terms of knowledge, attitude and practice. Specifically, the objective is to (1) identify the level of knowledge, attitude and practice of the social contract among Malaysian, (2) determine differences in knowledge, attitude and practice of the social contract according to gender, and (3) determine differences in knowledge, attitude and practice of the social contract according to ethnic.

\section{Research Methodology}

This study uses a cross-sectional design with a quantitative approach. A cluster sampling is used whereby a district in every state is randomly selected through the drawing of votes. The population chosen are Malays, Chinese and Indians in Peninsular Malaysia as the social contract in the context of Malaysia consists of this group. Samples chosen for the two pilot studies are 200 and 191 respondents. The research procedure involves several processes. Firstly, a review of past research based on the social contract and KAP (knowledge, attitude and practices) model. Secondly, discussions with five specialists in the field of ethnic relations and the constitution. Thirdly, the building of constructs and items which are distributed to specialists with experience in the field of sociology of constitutions and psychometric specialists of over 10 years. Fourthly, obtaining ethical approval (approved on 19 January 2021, code: USIM/JKEP/2021-122). Fifthly, the distribution of questionnaires for the pilot study to respondents in chosen locations through social media using Facebook advertisements. Finally, is the analysis of data using SPSS.

This study uses a self-developed questionnaire based on the Federal Constitution of Malaysia Articles 32, 38, 40, 41, 42, 44, 70, 3, 11, 153 and 152 as well as the KAP model. It is then reviewed by five specialists in the constitution field and two psychometric specialists. The questionnaire contains four (4) sections. Section A is regarding the knowledge of the social contract with an answer scale of true, false and do not know. The answer scale for Section $A$ is as follows

Table 1: Section A answer scale

\begin{tabular}{ll}
\hline Level & Scale \\
\hline Low & $0-0.33$ \\
Moderate & $0.34-0.66$ \\
High & $0.67-1.00$ \\
\hline
\end{tabular}

Section B concerns the attitude towards to traditional elements with the answer scale 1 (strongly disagree) to 5 (strongly agree). Section $C$ is in reference to the practice of the traditional elements with an answer scale of never, once, sometimes (2-3 times), often (4-5 
times) and very often (more than 5 times). Finally, Section D is the demographic background of the respondents. The answer scale for Section B and C are as follows

Table 2: Section B and C answer scale

\begin{tabular}{ll}
\hline Level & Scale \\
\hline Low & $1-2.33$ \\
Moderate & $2.34-3.66$ \\
High & $3.67-5.00$ \\
\hline
\end{tabular}

This study has gone through a reliability test for the first time on the 200 respondents on social media in all over the states in Peninsular Malaysia. Results show that there are two (2) items that need to be removed and two (2) items that need to be added. The results of the first pilot study are as below

Table 3: Reliability Results

\begin{tabular}{lll}
\hline Construct & Cronbach's Alpha $(\alpha)$ & Result \\
\hline Pilot study & Section A (17 items): 0.643 & No items removed, add 1 item \\
$\mathbf{1}$ & Section B (17 items): 0.755 & Maintain \\
$\mathbf{( N = \mathbf { 2 0 0 } )}$ & Section C (11 items): 0.492 & Remove item C2\&C5 ( $\alpha=0.622)$, add 1 item \\
\hline Pilot study & Section A (18 items): 0.750 & \\
$\mathbf{2}$ & Section B (17 items): 0.872 & Maintain all items \\
$\mathbf{( N = 1 9 1 )}$ & Section C (10 items): 0.718 & \\
\hline
\end{tabular}

After modifications are made, the questionnaire is distributed to different respondents all over Peninsular Malaysia on social media. As a result, 191 respondents are obtained. The reliability of this research is good as all sections obtained an alpha $(\alpha)$ value of more than 0.7 as in the table above.

\section{Social Contract in the Federal Constitution}

The social contract was introduced as early as the 17th century in the Western world to discuss issues on equality or justice by Hobbes (1651); Locke (1690); Rousseau (1763). However, the connotation of the social contract in the social system of Malaya is different from the Western pioneer's point of view. MacKinnon and Fiala (2018) states that the social contract is important to protect each individual in a society under a law or agreement that instils social collaboration. According to them, the social contract idea was introduced by Hobbes (1651), a $17^{\text {th }}$ century English philosopher, in his book The Leviathan. Thomas Hobbes was of the opinion that the social contract is an agreement that is used to preserve each individual's interests for their peace and safety respectively. Therefore, every individual must concur with the already agreed upon and enforced agreement by a sovereign. Apart from Thomas Hobbes, the idea of a social contract was also brought forth by other philosophers namely, Locke (1690); Rousseau (1763). Locke (1690) mainly touches on the State of Nature whereby in it consists of people with freedom towards nature. The social contract idea conveyed by John Locke is easier understood upon reviewing literatures by Western scholars that have been encapsulated in the social contract theory. Rousseau (1762) states that the social contract theory prioritises voice, rights and the individual ( $m a n$ ) instead of the country. The contract must also be obeyed by every individual involved. If it is not obeyed thus, the contract is void. Scanlon (1998); Gauthier (1987); Rawls (1971) also contributed ideas with 
regards to the social contract in the fields of moral theory and contemporary politics. Scanlon, Gauthier and Rawls state that the social contract idea is a moral rule voluntarily agreed upon by all parties for their own personal interest (MacKinnon \& Fiala, 2018). It can be summarised that according to Western philosophers, the social contract is an agreement that is collectively agreed upon in the society for the sake of common interest that needs to be obeyed by all and enforced as national law.

The social contract or traditional elements in the Federal Constitution is a term used to illustrate four traditional elements or those agreed upon among the Malay, Chinese and Indian race that have been written in the Federal Constitution. The four elements are the Malay language as the official language of Malaya where languages of other races are free to be used, Islam as the Federal religion where other religions are free to be practised by other believers, the monarchical institution and the special rights of the Malay people as well as the rights of non-Malays (Abas, 1985).

Traditional elements according to Abas (1985) is the collective agreement during the formation of the 1957 Federation of Malaya constitution. Tradition is a continuity from one generation to the next and traditional elements refer to a pre-existing system which depends on religious issues and other former values before the birth of the modern era (Muslim et al., 2013). It is in line with the definition of "Malay" in the Federal Constitution which is an individual who is Muslim, commonly speaks in Malay and practices Malay traditions. Therefore, all these elements are included as elements that are traditionally brought from pre-existing laws in Malaya to the Federal Constitution following the condition of the local society by the British (Abas updated by Buang, 1997).

Traditional elements and the social contract are terms with different meanings. However, in the context of the Federal Constitution of Malaysia, both terms are used to depict the same elements. Although the term social contract is more popular, its usage often brings about conflict and gives rise to dispute among citizens who are unclear about the history of the formation of Malaysia as a country (Hj Ikhsan \& Ahmad, 2014). The table below shows the traditional elements or the social contract within the Federal Constitution (Attorney General Chambers, 2010)

Table 4: Traditional elements or the social contract in the Federal Constitution

\begin{tabular}{|c|c|}
\hline Element & Federal Constitution Content \\
\hline 1. Monarchical System & $\begin{array}{l}\text { Article } 32 \text {, Article } 38 \text {, Article } 40 \text {, Article } 41 \text {, } \\
\text { Article } 42 \text {, Article } 44 \text {, Article } 70\end{array}$ \\
\hline 2. Islam and other religions & Article 3, Article 11 \\
\hline $\begin{array}{l}\text { 3. Special rights of Malays and Bumiputera } \\
\text { and the rights of other ethnics }\end{array}$ & Article 153 \\
\hline 4. The Malay language and other languages & Article 152 \\
\hline
\end{tabular}

The table above clarifies that all the elements in the traditional elements or social contract of the Federal Constitution is clearly written in legal language. However, the general public will understand all these elements better through clear descriptions using simple language from the writings of law experts for instance in literature by Abas (1985); Muslim and Buang (2012); Muslim et al (2011); Muslim (2012); A. Aziz (2012); Wan Husain et al. (2017). Traditional elements or the social contract in the Federal Constitution consists of the four elements listed above. The first being monarchy as stated in Articles 32, 38, 40, 41, 42, 44, 70 as follows: 
"32.(1) There shall be a Supreme Head of the Federation, to be called the Yang di-Pertuan Agong, who shall take precedence over all persons in the Federation and shall not be liable to any proceedings whatsoever in any court except in the Special Court established under Part XV."

"38.(1) There shall be a Conference of Rulers which shall be constituted in accordance with the Fifth Schedule. (2) The Conference of Rulers shall exercise its functions of - (a) electing, in accordance with the provisions of the Third Schedule, the Yang di-Pertuan Agong and Timbalan Yang di-Pertuan Agong; (b) agreeing or disagreeing to the extension of any religious acts, observances or ceremonies to the Federation as a whole; (c) consenting or withholding consent to any law and making or giving advice on any appointment which under this Constitution requires the consent of the Conference or is to be made by or after consultation with the Conference; (d) appointing members of the Special Court under Clause (1) of Article 182; (e) granting pardons, reprieves and respites, or of remitting, suspending or commuting sentences, under Clause (12) of Article 42 , and may deliberate questions of national policy (for example changes in immigration policy) and any other matter that it thinks fit..."

"40.(1) In the exercise of his functions under the Constitution or federal law, the Yang di-Pertuan Agong shall act in accordance with the advice of the Cabinet or of the Minister acting under the general authority of the Cabinet, except as otherwise provided by this Constitution; but shall be entitled, at his request, to any information concerning the government of the Federation which is available to the Cabinet. (1a) In the exercise of his functions under the Constitution or federal law, where the Yang di-Pertuan Agong is to act in accordance with advice, on advice, or after considering advice, the Yang di-Pertuan Agong shall accept and act in accordance with such advice. (2) The Yang di-Pertuan Agong may act in his discretion in the performance of the following functions, that is to say: (a) the appointment of a Prime Minister; (b) the withholding of consent to a request for the dissolution of Parliament; (c) the requisition of a meeting of the Conference of Rulers concerned solely with the privileges, position, honours and dignities of Their Royal Highnesses, and any action at such a meeting, and in any other case mentioned in this Constitution."

"41.The Yang di-Pertuan Agong shall be the Supreme Commander of the armed forces of the Federation."

"42.(1) The Yang di-Pertuan Agong has power to grant pardons, reprieves and respites in respect of all offences which have been tried by court-martial and all offences committed in the Federal Territories of Kuala Lumpur, Labuan and Putrajaya;"

"44.The legislative authority of the Federation shall be vested in a Parliament, which shall consist of the Yang di-Pertuan Agong and two Houses of Parliament to be known as the Senate and the House of Representatives." 
"70.Subject to the precedence of the Yang di-Pertuan Agong and his Consort, the Rulers and Yang di-Pertua Negeri of the States shall take precedence over all other persons and each Ruler or Yang di-Pertua Negeri shall in his own State take precedence over the other Rulers and Yang di-Pertua Negeri."

Traditionally, the Malay society has been practicing the monarchical system for centuries until colonizers interfered with administrative matters during the introduction of the Malayan Union in 1946 by the British. The power of Sultans was eliminated resulting in anger within the Malay people thus, the Malayan Union was abolished and replaced with the 1948 Federal Constitution of Malaya. By way of the constitution, the power of Sultans was restored until Malaya achieved independence, the power of Sultans was adapted in line with the concept of parliament and independence (Abas updated by Buang, 1997). Following all the contents of the Federal Constitution, it was found that the Yang di-Pertuan Agong was mentioned in the Federal Constitution, 437 times. However, the main issue meant to be brought forth with regards to traditional elements of the Federal Constitution, concerns the monarchical system whereby the Yang di-Pertuan Agong is the Supreme Head of Malaysia, Supreme Commander of the armed forces of the Federation, is the highest member in legislative authority of the Federation under Parliament, grants pardons and reprieves to all offences tried by Courtmartial for all offences committed in the Federal Territories of Kuala Lumpur, Labuan and Putrajaya, and he shall take precedence over all other persons in his country. He also has the right to appoint the Prime Minister, withhold the consent to a request for the dissolution of Parliament, assemble a meeting of the Conference of Rulers concerned solely with the privileges, position, honours and dignities of Their Royal Highnesses, and any action at such a meeting, and in any other case mentioned in the Federal Constitution. According to Abas updated by Buang (1997), the Constitution allocates that the Yang di-Pertuan Agong, all Rulers and governors shall often convene in order to create a good working relationship. This can be realised through the establishment of the Conference of Rulers. The Conference of Rulers was initiated during the inception of the Malayan Union and continues till today. It functions as written in Article 38 and the Fifth Schedule. Subsequently, with regards to the King's immunity and sovereignty, Article 32(1) states that the Yang di-Pertuan Agong shall not be liable to any proceedings whatsoever in any court except in the Special Court. No amendment can be made regarding the Conference of Rulers as well as the privileges, position, honours and dignities of Their Royal Highnesses unless agreed upon by the Conference of Rulers.

Secondly, Islam as the Federal religion as in the text from Articles 3 and 11 below:

"3.(1) Islam is the religion of the Federation; but other religions may be practised in peace and harmony in any part of the Federation."

"11.(1) Every person has the right to profess and practise his religion and, subject to Clause (4), to propagate it. (2) No person shall be compelled to pay any tax the proceeds of which are specially allocated in whole or part for the purposes of religion other than his own. (3) Every religious group has the right- (a) to manage its own religious affairs; (b) to establish and maintain institutions for religious or charitable purposes; and (c) to acquire and own property and hold and administer it in accordance with law. (4) State law and in respect of the Federal Territories of Kuala Lumpur, Labuan and Putrajaya, federal law may control or restrict the propagation of any religious doctrine or belief among persons professing the religion of Islam." 
Islam is the religion of Malaysia, nonetheless, other religions may be practised in harmony. There is a balance between Muslims and believers of other religions in Malaysia. In order to preserve the sanctity of Islam as the Federal religion, other religions cannot be propagated to Muslims. Traditionally, Islam has been practised by Malays in the last 500 years, perhaps even earlier and strong religious beliefs resulted in the failure of the Portuguese and Dutch to propagate their religion to the Malays (Abas updated by Buang, 1997). Ever since the British rule, Islam was not disturbed by them. As the head of Islam, the Yang di-Pertuan Agong is responsible to maintain the sanctity of the religion. Every religion in Malaysia has the right to manage their own religion without disturbance, to develop their own institutions and maintain as well as administer it in accordance with law. No one can be compelled to pay taxes for the purpose of other religions.

Thirdly, the Malay language being the national language as written in Article 152 as follows:

"(1) The national language shall be the Malay language and shall be in such script as Parliament may by law provide. Provided that- (a) No person shall be prohibited or prevented from using (otherwise than for official purposes), or from teaching or learning, any other language; and (b) Nothing in this Clause shall prejudice the right of the Federal Government or of any State Government to preserve and sustain the use and study of the language of any other community in the Federation."

The Malay language is Malaysia's national language however, other languages are free to be used by whomever. The Malay language has a bigger role as a national language than as an official language (Abas updated by Buang, 1997). Other languages apart from the Malay language can also be learnt and taught by anyone. Nevertheless, for official purposes, Malaysians must only use the Malay language. Official here meaning any matter involving matters of the Federal Government, State Government or matters pertaining to local authorities.

Lastly, the final traditional element is the special rights of Malays and Bumiputera as well as other ethnics. The essence of it can be referred to in Article 153 as below:

"(1) It shall be the responsibility of the Yang di-Pertuan Agong to safeguard the special position of the Malays and natives of any of the States of Sabah and Sarawak and the legitimate interests of other communities in accordance with the provisions of this Article. (2) Notwithstanding anything in this Constitution, but subject to the provisions of Article 40 and of this Article, the Yang di-Pertuan Agong shall exercise his functions under this Constitution and federal law in such manner as may be necessary to safeguard the special position of the Malays and natives of any of the States of Sabah and Sarawak and to ensure the reservation for Malays and natives of any of the States of Sabah and Sarawak of such proportion as he may deem reasonable of positions in the public service (other than the public service of a State) and of scholarships, exhibitions and other similar educational or training privileges or special facilities given or accorded by the Federal Government and, when any permit or licence for the operation of any trade or business is required by federal law, then, subject to the provisions 
of that law and this Article, of such permits and licences. (3) The Yang di-Pertuan Agong may, in order to ensure in accordance with Clause (2) the reservation to Malays and natives of any of the States of Sabah and Sarawak of positions in the public service and of scholarships, exhibitions and other educational or training privileges or special facilities, give such general directions as may be required for that purpose to any Commission to which Part $X$ applies or to any authority charged with responsibility for the grant of such scholarships, exhibitions or other educational or training privileges or special facilities; and the Commission or authority shall duly comply with the directions. (4) In exercising his functions under this Constitution and federal law in accordance with Clauses (1) to (3) the Yang di-Pertuan Agong shall not deprive any person of any public office held by him or of the continuance of any scholarship, exhibition or other educational or training privileges or special facilities enjoyed by him."

The Yang di-Pertuan Agong is responsible to the maintain the special rights of Malays and Bumiputera of Sabah and Sarawak as well as the legitimate interests of other ethnics. He must also protect the rights of the Malays and Bumiputera of Sabah and Sarawak for example the reserved lands, positions in the public service, scholarships, exhibitions and educational privileges and permits or trade and business licences. Nonetheless, Article 153 Clause 4 explains that every right listed in Clause 1 and 3 cannot be deprived of their positions or rights of those already holding said positions.

As a whole, traditional elements or the social contract is an element or agreement that has been acknowledged and is rightfully an element of the Federal Constitution as history proves that a native of this country has the right to be given fair treatment without forsaking the rights of other races that has fought for independence together. This agreement and consensus need to be balanced between the rights of the natives which are the Malays and Bumiputera with other races in Malaysia whose citizenship has been recognised. Malaysians must be clear about the country's history and learn from all that has happened in the country in order to avoid the harmony that has been achieved from being threatened.

\section{Traditional Elements of the Federal Constitution in Uniting the Races in Malaysia.}

Articles considered advantageous to certain ethnics in the Federal Constitution are balanced with other provisions that are also favourable to other ethnics. For example, the article that sets Islam as the religion of the federation is balanced with the allocation of freedom for every citizen to believe and practise any religion harmoniously. This also applies to the article that sets the Malay language as the national language which is also balanced with the provision by which no person can be prohibited from using (otherwise than for official purposes) or teaching or learning any other language. Similarly, the article that places the special position of Malays and Bumiputera of Sabah and Sarawak which is balanced with the provision whereby the government cannot deprive, withdraw or cause the rights of other ethnics to be jeopardised. This denotes that the understanding of Islam as the federal religion, the Malay language as the national language and the special position of Malays and Bumiputera of Sabah and Sarawak must be read and internalised through the philosophy of balance and does not merely stop at the statement of them being the federal religion, national language and special position of Malays and Bumiputera of Sabah and Sarawak.

The provision under Article 3 explains that Islam is the religion of the federation; but other religions can be practised in peace and tranquillity anywhere in the Federation. The 
provision in Article 3 is clearly balanced by the fact that other religions can be practised in peace and tranquillity anywhere in the Federation. For non-Muslims, they are given the freedom to practise their beliefs and religious ceremonies according to their way of life. There are three arguments regarding the provision of Islam in the constitution. Firstly, at the time, no less than 15 countries in the world allocated the provision of religion in their constitutions, whether the majority of its citizens are Christians, Muslim or even Buddhists. Among the countries that allocated the provision of religion in their constitutions at the time include Christian countries namely, Ireland (Article 6), Norway (Article 1), Denmark (Article 3), Spain (Article 6), Argentina (Article 2), Bolivia (Article 3), Panama (Article 36), and Paraguay (Article 3), Muslim countries namely, Afghanistan (Article 1), Iran (Article 1), Iraq (Article 13), Jordan (Article 2) and Syria (Article 3) and a Buddhist country which was Thailand (Article 7). Secondly, countries allocating the provision of religion in their constitutions did not give any hardship to their citizens. Thirdly, the provision of Islam did in fact exist in the Constitution of the States of Malaya for instance Johor and Terengganu. Therefore, it only needs to be added into the Federal Constitution. This is in line with history and practices in this country whereby Islam has a high position and influence ever since before independence.

Regarding the provision of the Malay language in the Constitution, it is clear that in Article 152, the Malay language is the National language and shall be in such script as Parliament may by law provide on condition that no person can be prohibited or prevented from using (otherwise than for official purposes), or from teaching or learning any other language; and there is none whatsoever in this Clause that can jeopardise the rights of the Federal Government or the rights of any State Government to maintain and continue the usage and teaching of the language of any other race in the Federation. This is because during the formation of the constitution, the previous leaders have decided that an independent state cannot continue to use the English language as the official language if it wishes to unite its people, even more so in a plural society. Therefore, non-Malays must accept the Malay language as the national language and at the same time the Malays should accept the rights of non-Malays to use and learn their mother tongue as stated in the constitution. In the context of a multi-ethnic society, it is apparently difficult for each ethnic to compromise regarding issues of culture and religion as it is rather sensitive. Hence, only language can be compromised to be shared together in which the Malay language acts as a unifying tool for ethnics in Malaysia.

On the other hand, Article 153 explains that it is the responsibility of the Yang di-Pertuan Agong to guarantee the special position of Malays and also to protect the rights of other races. The main point requiring attention and internalisation during the process of formulating the constitution is the spirit of understanding, accommodating, sharing of power and willingness to sacrifice amongst the Malays and non-Malays. As citizens, this needs to be internalised as the constitution is the highest law in the country and used as reference. During the formulation process, several suggestions were considered for agreement. In this process, there was accommodating spirit between Malays and non-Malays regarding their respective interests otherwise known as the social contract. For example, the Malay ethnic loosened the citizenship requirements for non-Malays while the non-Malays accepted the special position of the Malay ethnic. At the time, the Malay ethnic accepted the jus soli principle which grants citizenship for those who were born after independence and a looser citizenship for nonMalay ethnics born before independence.

The Malay language, Islam, special rights of Bumiputera and the monarchical system that is stated in the Federal Constitution was written without forsaking the language, religion 
and rights of other races. Although the Malay language is the national language of Malaysia, other languages can be used freely, as well as learnt and taught to anyone. With one language used officially for official purposes, other races indirectly learn and understand the Malay language well. When all Malaysians use the same language for official affairs, interracial unity can be strengthened. Language is an intermediary medium and an important tool of communication for the conveying of information and human interaction. When society is able to communicate well, all the information and misunderstandings as well as interracial dialogues can be imparted clearly. The same goes with religion. Although Islam is the official religion, other religions can be practised in peace and harmony without interference. Islam is not hostile towards other religions; Islam is a religion that promotes peace. Allah SWT says, that which means:

"O humanity! Indeed, We have created you from a male and a female, and We have made you into peoples and tribes so that you may get to know one another (and be friendly with each other). Surely the most noble of you in the sight of Allah is the most righteous among you, (not those of better ancestry or race). Allah is truly All-Knowing, All-Aware (of your circumstance and deeds)" (Surah alHujurat 49: 13).

This clearly shows that Islam is a religion that encourages interracial unity. We are encouraged to get to know one another and build ties with each other regardless of race and ancestry. Every human is the same, there is no difference. The only distinguishing factor being their righteousness to Allah SWT. Besides that, the special rights of Bumiputera are seen as fair because traditionally, they are the natives of this country. Nonetheless, the legitimate rights of other races are not denied and all the rights owned by other races cannot be confiscated or refuted. This fair attitude can strengthen and realise racial unity in Malaysia. Lastly, led by the Yang di-Pertuan Agong, every Malaysian citizen under the same rule must be treated fairly and justly. Hence, it is wise for every citizen regardless of race and belief to be obedient and loyal to the Yang di-Pertuan Agong in order to continue living in harmony without triggering chaos.

\section{Research Findings and Discussion}

Background of respondents

Table 1: Background of respondents

\begin{tabular}{lll}
\hline Category & & Frequency (Percentage) \\
\hline Gender & Male & $81(42.4)$ \\
& Female & $110(57.6)$ \\
Relhnic & Malay & $94(49.2)$ \\
& Chinese & $66(34.6)$ \\
& Indian & $31(16.2)$ \\
& Muslim & $97(50.8)$ \\
& Buddhist & $51(26.7)$ \\
& Hindu & $26(13.6)$ \\
& Christian & $10(5.2)$ \\
& Others & $7(3.6)$ \\
\hline
\end{tabular}

There were 191 research respondents, whereby female respondents were more than male respondents. The Malay ethnic were as many as 94 people, followed by the Chinese 
ethnic of 66 people and the Indian ethnic of 31 people. In terms of belief, 97 people were Muslims, followed by 51 Buddhists, 26 Hindus and 10 Christians.

Level of Knowledge, Attitude and Practice of the Traditional elements

Overall, the level of knowledge, attitude and practice of the traditional elements is generally high. The min of the practice of the traditional elements is higher than the min of attitude and knowledge. The table below shows the min value for every section.

Table 2: Level of knowledge, attitude and practice of the traditional elements

\begin{tabular}{lll}
\hline Section & Mean & Level \\
\hline Knowledge & 0.8554 & High \\
Attitude & 4.2701 & High \\
Practice & 4.5021 & High \\
\hline
\end{tabular}

A detailed analysis of each item can be referred to the table below.

Table 7: Details of each item

\begin{tabular}{|l|l|l|}
\hline Knowledge & Mean & SD \\
\hline 1. The tradition element in Federal Constitution consist of Malay & 0.8482 & 0.3598 \\
Language, Islam, special position of the Malays and the & & \\
institution of monarchy. & 0.9948 & 0.0724 \\
2. The Malay language is the national language in the Federal & 0.9686 & 0.1749 \\
Constitution. & & \\
3. The Malay language is used as the medium in all official & 0.9162 & 0.2778 \\
government matters. & 0.9529 & 0.2125 \\
4. Languages other than English can be learned by anyone. & & \\
5. The Chinese and Indian ethnicities can use their mother tongue & 0.9581 & 0.2009 \\
in their daily affairs. & 0.9843 & 0.1247 \\
6. Islam is the religion of the Federation in the Federal & 0.6702 & 0.4714 \\
Constitution. & & \\
7. Other religions can be practised in Malaysia. & 0.8115 & 0.3921 \\
8. According to the Federal Constitution, believers of other & & \\
religions other than Islam cannot spread their religion to & 0.9372 & 0.2433 \\
Muslim believers. & 0.9319 & 0.2525 \\
9. Believers of other religions can manage their own religious & & \\
affairs without restriction. & 0.7382 & 0.4408 \\
10. The special position of the Malays is constituted in the Federal \\
Constitution.
\end{tabular}


14. The Yang di-Pertuan Agong is the Supreme Head of Malaysia.

15. The Yang di-Pertuan Agong can act at his discretion to appoint the Prime Minister.

16. The Yang di-Pertuan Agong can act at his discretion to withhold the consent to a request for the dissolution of parliament.

17. The provisions of the special position of the Malays, Islam, the Malay language and the institution of monarchy cannot be amended, even in the state of Emergency.

18. Any amendment to the provisions of the special position of the Malays, Islam, the Malay language and the institution of monarchy, requires a $2 / 3$ majority in Parliament and the consent of the Conference of Rulers.

\section{Attitude}

1. I accept the use of the Malay language in official government matters.

2. I am ashamed to speak in the Malay language because it seems backward.

3. I am proud of the Malay language as the national language.

4. I feel comfortable using the Malay language in everyday life.

5. I can accept if other ethnicities use their respective languages in their daily lives.

6. I accept Islam as the religion of the Federation in Malaysia.

7. The propagation of other religions to Muslims is not allowed.

8. Believers of other religions should be given the freedom to practise their respective religions.

9. Believers of other religions should manage their own religious affairs without restriction.

10. I accept the special position of the Malays with regard to the issuing of permits or licenses.

11. I accept the special position of the Malays with regard to the appointments in public service posts.

12. I accept that there are special provisions for the Malays in the admission to public higher education in Malaysia.

13. I am proud that the Yang di-Pertuan Agong is the supreme head of Malaysia.

14. I accept that the Yang di-Pertuan Agong has the authority in Islamic religious affairs.

15. I agree that Yang di-Pertuan Agong has the power in matters related to the special position of the Malays.

16. I accept that the provisions of the special position of the Malays, Islam, the Malay language and the institution of monarchy cannot be amended, even in the state of Emergency.

17. Any amendment to the provisions of the special position of the Malays, Islam, the Malay language and the institution of monarchy, requires a $2 / 3$ majority in Parliament and the consent of the Conference of Rulers. 
1. I openly accept the tradition element (Malay Language, Islam, special position of the Malays and the institution of monarchy) stated in the Federal Constitution of Malaysia.

2. I use the Malay language in all official government matters.

3. I use my mother tongue in my daily affairs.

4. I express anger over the noise disturbance that resulted from

\begin{tabular}{|l|l|}
\hline 4.1309 & 1.1419 \\
4.5707 & 0.8360 \\
4.5864 & 0.8594 \\
1.5079 & 0.8758 \\
& \\
1.5236 & 0.8755 \\
4.7487 & 0.5801 \\
1.2513 & 0.7467 \\
1.6283 & 1.1206 \\
& \\
1.5183 & 1.0303 \\
1.5864 & 1.0670 \\
\hline
\end{tabular}
religious activities (for example: the call to prayer [azan], church or temple bells, and others).

5. I express dissatisfaction towards some of the other ethnicities' religious activities.

6. I obey the command of the Yang di-Pertuan Agong.

7. I express my dissatisfaction towards the Yang di-Pertuan Agong.

8. I object to the provisions of the Malays' admission to the public higher education.

9. I object to the issuing of permits or licenses to the Malays.

10. I object to the provisions of the Malays' appointment in the public service posts.

According to the table above, the knowledge of the traditional elements variable is generally high. The answer scale used for the knowledge variable is from 0 to 1 . Hence, a high min level is from 0.67 to 1.00 . However, findings show that several items are at the border of high and medium. This means that some items are still less understood by respondents to be the content of the traditional elements of the Federal Constitution. Those items are "According to the Federal Constitution, believers of other religions other than Islam cannot spread their religion to Muslim believers", "The legitimate interests of the Chinese and Indians in public higher education institutions, permits or licenses and public services cannot be taken away" and "Any amendment to the provisions of the special position of the Malays, Islam, the Malay language and the institution of monarchy, requires a $2 / 3$ majority in Parliament and the consent of the Conference of Rulers". As for the attitude and practice variable, the answer scale is from 1 to 5 . All the answers for every item are at a high scale however, there are several items that are almost at the border of medium and high. The items are "I accept that there are special provisions for the Malays in the admission to public higher education in Malaysia", "I accept the special position of the Malays with regard to the appointments in public service posts", "I accept the special position of the Malays with regard to the issuing of permits or licenses", "The propagation of other religions to Muslims is not allowed" and "Any amendment to the provisions of the special position of the Malays, Islam, the Malay language and the institution of monarchy, requires a $2 / 3$ majority in Parliament and the consent of the Conference of Rulers". These findings show that there are a handful of individuals that do not quite agree with the privilege given to the Malays that have been decreed in the Federal Constitution. The difference in acceptance is proved to exist according to ethnic.

\section{Difference in Knowledge, Attitude and Practice of the Traditional elements According to Gender}

The results of the analysis on the difference between genders regarding knowledge, attitude and practice of the traditional elements shows that all the variables do not show a difference according to gender. 
Table 8: Difference in knowledge, attitude and practice according to gender

\begin{tabular}{llllll}
\hline Variable & Gender (N) & Mean (M) & $\begin{array}{l}\text { Standard } \\
\text { Deviation } \\
(\text { SP) }\end{array}$ & $\begin{array}{l}\text { T Value } \\
(\mathbf{t})\end{array}$ & $\begin{array}{l}\text { Significance } \\
(\mathbf{p})\end{array}$ \\
\hline Knowledge & Male (81) & 0.8717 & 0.1466 & 1.389 & 0.167 \\
& Female (110) & 0.8434 & 0.1284 & & \\
\hline Attitude & Male (81) & 4.3362 & 0.6425 & 1.279 & 0.203 \\
& Female (110) & 4.2214 & 0.5717 & & \\
\hline Practice & Male (81) & 4.5309 & 0.4865 & 0.693 & 0.489 \\
& Female (110) & 4.4809 & 0.5004 & & \\
\hline
\end{tabular}

There is no significant difference $(\mathrm{t}=1.389, \mathrm{df}=158.7)$ between males $(\mathrm{M}=0.8717, \mathrm{SP}=$ $0.1466)$ and females $(M=0.8434, S P=0.1284)$ in knowledge of the traditional elements. Similarly for attitude towards the traditional elements, there is no significant difference $(\mathrm{t}=$ $1.279, \mathrm{df}=160.4)$ between males $(\mathrm{M}=4.3362, \mathrm{SP}=0.6425)$ and females $(\mathrm{M}=4.2214, \mathrm{SP}=$ $0.5717)$. With regards to practice of the traditional elements, there is no significant difference $(\mathrm{t}=0.693, \mathrm{df}=175.2)$ between males $(\mathrm{M}=4.5309, \mathrm{SP}=0.4865)$ and females $(\mathrm{M}=4.4809, \mathrm{SP}$ $=0.5004)$.

Difference in Knowledge, Attitude and Practice of the Traditional elements According to Ethnic Results show a significant difference between the Malay, Chinese and Indian ethnics with regards to knowledge, attitude and practice of the traditional elements. In terms of knowledge of the traditional elements, the Malay ethnic is more knowledgeable $(M=0.8824$, $\mathrm{SP}=0.1102)$ compared to other ethnics, followed by the Indian ethnic $(\mathrm{M}=0.8315, \mathrm{SP}=$ $0.1682)$ and the Chinese ethnic $(M=0.8283, S P=0.1490)$. As for attitude as well, the Malay ethnic $(M=4.5807, S P=0.4718)$ has a better attitude towards the traditional elements, followed by the Indian ethnic $(M=4.0019, S P=0.5519)$ and the Chinese ethnic $(M=3.9537$, $\mathrm{SP}=0.5754)$. Similarly with the practice of the traditional elements, the Malay ethnic $(\mathrm{M}=$ 4.6596, $\mathrm{SP}=0.4115)$ practises the contents of the traditional elements more, followed by the Chinese ethnic $(M=4.3848, S P=0.4871)$ and the Indians $(M=4.2742, S P=0.5865)$. 
Table 9: Difference in knowledge, attitude and practice according to ethnic

\begin{tabular}{|c|c|c|c|c|c|c|}
\hline & Ethnic & $\begin{array}{l}\text { Total sum } \\
\text { of squares }\end{array}$ & $\begin{array}{l}\text { Degree of } \\
\text { freedom }\end{array}$ & Mean $^{2}$ & $\begin{array}{l}\text { F } \\
\text { Value }\end{array}$ & $\mathbf{P}$ \\
\hline \multirow[t]{4}{*}{ Knowledge } & \multirow{2}{*}{$\begin{array}{l}\text { Between } \\
\text { groups }\end{array}$} & 0.135 & 2 & .067 & \multirow[t]{4}{*}{3.701} & \multirow[t]{4}{*}{.027} \\
\hline & & 3.420 & 188 & .018 & & \\
\hline & Within groups & 3.555 & 190 & & & \\
\hline & Total & & & & & \\
\hline \multirow[t]{4}{*}{ Attitude } & \multirow{2}{*}{$\begin{array}{l}\text { Between } \\
\text { groups }\end{array}$} & 17.909 & 2 & 8.954 & \multirow[t]{4}{*}{32.779} & \multirow[t]{4}{*}{.000} \\
\hline & & 51.358 & 188 & 0.273 & & \\
\hline & Within groups & 69.267 & 190 & & & \\
\hline & Total & & & & & \\
\hline \multirow[t]{4}{*}{ Practice } & \multirow{2}{*}{$\begin{array}{l}\text { Between } \\
\text { groups }\end{array}$} & 4.849 & 2 & 2.424 & \multirow[t]{4}{*}{10.985} & \multirow[t]{4}{*}{.000} \\
\hline & & 41.491 & 188 & .221 & & \\
\hline & Within groups & 46.339 & 190 & & & \\
\hline & Total & & & & & \\
\hline
\end{tabular}

Table 10: Mean difference in knowledge, attitude and practice according to ethnic

\begin{tabular}{llll}
\hline Variable & Ethnic & Mean & SP \\
\hline Knowledge & Malay & 0.8824 & 0.1102 \\
& Chinese & 0.8283 & 0.1490 \\
& Indian & 0.8315 & 0.1682 \\
\hline Attitude & Malay & 4.5807 & 0.4718 \\
& Chinese & 3.9537 & 0.5754 \\
& Indian & 4.0019 & 0.5519 \\
\hline Practice & Malay & 4.6596 & 0.4115 \\
& Chinese & 4.3848 & 0.4871 \\
& Indian & 4.2742 & 0.5865 \\
\hline
\end{tabular}

Although the knowledge, attitude and practice of the traditional elements is high, there is a difference in the min value according to ethnics. This is because most of the questions on the traditional elements revolve around the interests of Bumiputera. Questions given to the respondents were about the Malay language, Islam, special rights of the Bumiputera and the monarchical system.

\section{Conclusion}

The social contract or traditional elements in the Federal Constitution of Malaysia is often a controversy within the society. Although all the elements contained in the Federal Constitution emphasises the privilege of the natives of this country, other races that become citizens still have their legitimate interests acknowledged. They are free to practise their own beliefs and their own language in peace and harmony. The Yang di-Pertuan Agong as the head of state plays a role in uniting all the citizens of this country through his fair and just rule. Islam as the federal religion emphasises on peace among every individual in the society, and the Malay language should appropriately be the medium that unites the races in Malaysia. 
The result from the analysis of the provision of the traditional elements in the Federal Constitution depicts that receivers that are different according to ethnic and privilege given towards the Malays are less agreed upon by a handful of individuals. Finally, being historically literate is a basic matter that each individual needs to have to prevent misunderstandings and interracial conflicts. Therefore, this matter needs to be understood and internalised by every level of society, especially the younger generations in order for them to always keep an open heart regarding particular issues involving issues in the constitution.

\section{Acknowledgements}

This paper is a part of a research funded under the Ministry of Higher Education Malaysia under the Fundamental Research Grant Scheme (FRGS). Research title: Pembinaan indeks pengetahuan, pemahaman dan penghayatan kontrak sosial dalam Perlembagaan Persekutuan di Malaysia. Project Code: FRGS/1/2019/SS06/USIM/ 03/2.

\section{References}

Sariyan, A. (2014). Strategi Menjayakan Bahasa Melayu Sebagai Bahasa Negara. Jurnal Pertanika, 1(1), 1-18.

Gauthier, D. (1987). Morals by Agreement. Oxford University Press.

Hobbes, T. (1651). The Leviathan. In Longman Library of Primary Sources in Philosophy. https://doi.org/10.4324/9781315507613

Locke, J. (1690). The Second Treatise of Civil Government. University of Adelaide. https://doi.org/10.1002/jss.400090409

MacKinnon, B., \& Fiala, A. (2018). Ethics: Theory and Contemporary issues, Ninth Edition. Cengage Learning. https://doi.org/10.4324/9781315543758-6

Abas, M. S. (1985). Unsur-unsur tradisi dalam Perlembagaan Malaysia. Dewan Bahasa dan Pustaka.

Muslim, M., \& Buang, A. H. (2012). Islam Dalam Perlembagaan Persekutuan Dari Perspektif Hubungan Etnik Di Malaysia. Jurnal Kemanusiaan, 20(2), 115-129.

Muslim, M., Alias, J., Hassan, W. Z., Umar, A., \& Yunos, N. (2013). Analisis peruntukan orang Melayu dalam perlembagaan persekutuan Malaysia dalam konteks hubungan etnik. Jurnal Melayu, 11, 63-78.

Rawls, J. (1971). A Theory of Justice. Harvard University Press.

Rousseau, J. J. (1763). The Social Contract.

Scanlon, T. (1998). What We Owe Each Other. Harvard University Press.

Aziz, A. S. (2012). Kuasa dan Peranan Raja-Raja Melayu dalam Perlembagaan: Sejarah dan Masa Depan. Seminar Perlembagaan Malaysia: 'Di Antara Sejarah Dan Tuntutan Semasa,' 1-8. http://www.arkib.gov.my/documents/10157/6f1c6800-188b-4885-8ba8698102207ad1

Ikhsan, h. S. A., \& Ahmad, S. (2014). Kontrak Sosial Dalam Pengajaran Dan Pembelajaran Lisan: Tinjauan Terhadap Perspektif Pelajar. Procedia - Social and Behavioral Sciences, 134, 276-282. https://doi.org/10.1016/j.sbspro.2014.04.249

The Commissioner of Law Revision. (2010). Malaysia Federal Constitution 1957 (Reprint). The Commissioner of Law Revision.

http://www.agc.gov.my/agcportal/uploads/files/Publications/FC/Federal Consti (BI text).pdf

Husain, W. A. F., Che Ngah, A., \& Omar Din, M. A. (2017). Islam Agama Bagi Persekutuan: Satu Kajian Sejarah Perundangan. Akademika, 87(3), 177-193. 